\title{
Research on Zombie Enterprise
}

\author{
Zijiong Chen ${ }^{1, *}$ \\ ${ }^{1}$ Macau university of Science and Technology, Faculty of Law, Macau SAR 999078, China \\ *Corresponding author. Email: 964232084@qq.com
}

\begin{abstract}
With the decreasing marginal effect of macro-policy, the structural problems accumulated in the process of rapid development of China's economy since the reform and opening-up 40-odd years ago have begun to emerge, such as high debt, overcapacity of enterprises, declining return on investment, operational difficulties and even continuous losses. These "blood-sucking zombie enterprises" are gradually exposed to the public's eyes. These zombie enterprises have adverse effects on the future development of China, such as wasting social resources, disturbing market order, disengagement from asset supervision, harming workers' rights and interests, and forming financial risks. Based on logic analysis, this article analyzes the formation of zombie enterprises, the necessity of dealing with zombie enterprises and the solutions. The result shows that Zombie companies lead to misallocation of resources, occupying social capital, making it difficult for emerging companies to obtain funds, and hindering innovation and development. Bankruptcy disposal of zombie companies must pass strict legislation, law enforcement and legal supervision to effectively solve financial risks and protect the rights and interests of employees.
\end{abstract}

Keywords: Zombie enterprises, Restructuring, Bankruptcy, Debt, Government, Banks.

\section{INTRODUCTION}

The term "zombie enterprise" appeared in economist Edward. J. Kane's study of the long recession that hit Japan after the collapse of asset prices in the 1990s and refers to companies that received credit subsidies or that did not generate profits. An enterprise is an independent economic organization established in accordance with the law and engaged in commodity management for profit. Zombie companies, on the other hand, have no ability to make a profit, have no long-term loss and have no hope of turning around, and should have exited the market according to the laws of the market, but are in a "zombie state" because of the "blood transfusion" of governments and lenders (e.g. banks, etc.). Zombie companies are different from companies with troubled assets. They can quickly come back to life, and zombie businesses are characterized by sucking up social resources, such as financial subsidies, bank loans, and other physical and human resources, as their names do. In addition, zombie enterprises have the same ability to infect normal people as zombies. If a healthy business to merge and re-structure the "zombie enterprise", the healthy enterprises may be satisfied, dragged down, dragged to death, and then become the new "zombie enterprise."[1]

If banks continue to provide assistance to zombie companies, they may end up as "zombie banks". If a place has been subsidizing "zombie enterprises", the economy of this place will one day be dragged down by the zombie enterprises it helps to turn into a "zombie economy". This article discusses zombie enterprises and provides solutions in different aspects.

\section{SURVIVAL MODELS OF ZOMBIE ENTERPRISES}

\subsection{Dead Enterprises}

These enterprises cannot offset operating costs, have been in a state of suspension for a long time, or have been bankrupt or unable to repay related due debts, and have not processed corporate bond debts.

\subsection{The Explicit "Zombie Enterprise"}

The enterprises can still operate, but its income can no longer pay covering wages, management fees, 
raw materials costs, loan interest, taxes and so on, including all the contractors, so that the enterprise has lost money for years, in a state of high debt.

\subsection{Implicit "Zombie Enterprise"}

Implicit "zombie enterprise" appears to be healthy on the surface, but needs to rely on a sustained "blood transfusion" from outside (e.g. government) to maintain its operations, or is in a situation where it can only repay interest on its debt but cannot reduce its debt burden.

\section{THE FORMATION OF ZOMBIE ENTERPRISES}

\subsection{The Government Over-protects Businesses}

In order to promote the development of the local economy, local governments continue to encourage enterprises to invest in public utilities and competitive fields. But when these homogeneous investments encounter an economic downturn, they will become a burden for enterprises. [2, 10]

However, the government has collected and considered social stability for itself and will not let these problematic companies go bankrupt. It will continue to use financial subsidies and bank support to maintain the life of problematic companies. [3] The government hopes that the estimated risks will not be exposed in the short term, but the accumulated debt eventually turns these companies into "zombie companies".

\subsection{Structural Adjustment Factors}

With the development of society, in addition to normal enterprises, there are also some low-end industries (traditional raw material production), highpolluting high-energy enterprises (chemical industry; steel industry; non-ferrous metals industry; cement industry, etc.)[4]. Low-scatter enterprises refer to low output, low utilization of resources, low-tech content, small scale, distribution of such enterprises. Due to technical content, industrial structure adjustment, low value-added products, and difficult transformation and upgrading, it is impossible to realize the rational allocation of resources, provide the society with the products needed or useful products, services and job opportunities for workers, and finally leads to the above types of enterprises into "zombie enterprises".

\subsection{Strong Market Competition Environment}

Some enterprises are stuck in the fierce market competition for lack of independent innovation awareness of enterprises, products and services. There is no way to open up the gap with the same type of enterprises, seize the market opportunity, resulting in no market, no profit, debt accumulation, ultimately cannot keep up with the pace of the market, and become "zombie enterprises" in the end.

\subsection{The Development of Capital Market Lags Behind}

Lagging capital market development provides the conditions for the survival of listed "zombie enterprises". The stock market has a strong financing capacity, but as far as China is concerned, the exit mechanism is not perfect. "Shell resources" are scarce and listing status has great value. For 20 years, there have been just over 40 listed companies in which A-shares have actually been delisted as of 2016. As a listed company, many "zombie enterprises" take the strategy of raising funds, selling assets and equity, and converting government subsidies directly into profits to avoid de-marketing. Through asset restructuring and mergers and acquisitions, it will become "shell resources" sold at high prices.

\subsection{Obstacles to Some Institutional Mechanisms}

In today's social system, there are some obstacles limiting the exit of "zombie enterprises" according to market rules. First of all, enterprises in bankruptcy will lead to a large number of workers unemployed. If they are properly resettled, society will be more stable. The existence of "zombie companies" obscures the problems of certain banks. Therefore, banks are constantly providing support to "zombie companies" so that they can maintain their operations.

\section{THE NECESSITY TO DEAL WITH ZOMBIE ENTERPRISES}

\subsection{Saving Social Resources}

Since most zombie enterprises are state-owned enterprises, it is easier to get local government support and bank loans to help their own enterprises. There are also some zombie companies that are determined by local leading companies and people 
who have made great contributions to the local economy as having no business problems. These "zombie companies" occupy the country's land, capital, labor, technology, equipment, sales channels and other resources, but their production cannot keep up with the times, resulting in a waste of social resources and a huge impact on social and economic development. Therefore, the resources occupied and wasted by zombie companies can be reused and allocated effectively, which will help high-tech companies and enterprises develop better [5].

\subsection{Establishing Market Order}

"Zombie companies" occupy the living space of high-quality companies, leading to some high-quality companies not getting government policy support or bank loans. The brutal wave of competition in the market will eventually be eliminated, forming lowefficiency industries and expelling high-efficiency industries. Therefore, dealing with "zombie companies" is top priority, which can match production capacity with the market, thereby rejuvenating the market.

\subsection{Strengthening Asset Supervision}

"Zombie enterprise" is characterized by poor asset quality, complex property rights structure with assets ownership unclear and chaotic management phenomenon. Because of the difficulty of management and disposal, there are people in higher management departments walking around the problem. Inadequate supervision functions have led to a lack of supervision of state-owned assets. Clearing up "zombie enterprises" can eliminate asset ownership, and the responsible department can also assume corresponding responsibilities to stop losses in a timely manner and promote the preservation and appreciation of state-owned assets.

\subsection{Protecting the Rights and Interests of Employees}

Under the circumstances of insolvency and financing difficulties, "zombie companies" will default on the wages of their employees and damage the rights and interests of workers, which will affect workers' enthusiasm and lead workers to go to march. Therefore, when dealing with "zombie companies", employees do not need to wait for the company's solution to come to their door, but instead protecting their rights through subsidies, reemployment, and internal promotion.

\subsection{Protecting Against Financial Risks}

"Zombie enterprises" can only rely on the concept of "sucking blood" to survive, assuming that the government does not give subsidies, but relying on the bank's loan transfusion to survive. When the loan expires, if it cannot be repaid, they need to modify the repayment terms or borrow new debt to repay the old debt to survive. When banks are tied up by "zombie companies," they can only make the ledger look better by lending new loans to repay old debts. But once the country's credit policy is tightened, zombie companies will face the risk of bankruptcy and bank loans will be difficult to recover. According to the current situation, "zombie companies" are increasing, and risks are also increasing. Serious situations may even lead to financial crises. Against the backdrop of huge downward pressure on Chinese economic environment, measures to promote the disposal of "zombie companies" will have a positive impact on the efficiency of banks in dealing with non-performing assets and provide support for real estate.

\section{SOLUTIONS}

In the process of cleaning up "zombie enterprises", two unavoidable issues will be involved. One is the subsequent resettlement of enterprise workers. If they fail to provide protection for the lives of unemployed workers or provide new job opportunities, social stability will be affected. [6] Therefore, in accordance with the solvency of "zombie companies" and relevant laws and regulations, bankruptcy liquidation, bankruptcy reorganization, and mergers and reorganizations can be used to deal with remaining debts.

\subsection{Bankruptcy Liquidation}

Bankruptcy liquidation is suitable for companies whose debt situation is deteriorating and cannot be saved. From an accounting point of view, liquidation loses the main qualifications of the enterprise and finally terminates the enterprise's production and operation. [7]

After the court declares the enterprise bankrupt, it shall carry out liquidation and take over the company, and declare, liquidate, evaluate, dealing with and distribute the bankrupt property. The court will form a liquidation group by organizing corporate shareholders, state-owned management departments (e.g. SASAC), government departments, securities management departments, auditors, lawyers, evaluator, etc. The main task of the liquidation team 
is to report to the court and accept the supervision of the court. After giving priority to the payment of liquidation expenses, the bankruptcy property shall pay off the wages and social security expenses owed to the employees in order to protect the rights and interests of the employees, paying the taxes and fees owed, and finally paying off the bankruptcy claims.

\subsection{Bankruptcy Reorganization}

Insolvency reorganization applies to enterprises with heavy debt burdens, unable to repay debts through self-negotiated debt relief, lend through banks, restore the vitality of enterprises through normal operations, with high-quality assets and certain investment value. The core of bankruptcy restructuring lies in how the court can solve the debt problem of "zombie enterprises" through the restructuring procedure to safeguard the interests of all parties. Unlike liquidation, bankruptcy restructuring is a business that is on the verge of bankruptcy, and within a limited period of time, it is possible to recover its debts through restructuring. Reorganization is a systematic work, which requires all parties involved to work closely in order to achieve the goal of making the target enterprise come back from the dead, thus interfering with the protection of the rights and interests of all parties.

In the reorganization procedure, the manager is responsible for the main affairs, and the court is the final arbiter. All important matters in the reorganization (accepting the reorganization application, confirming the creditor's rights, confirming the resolutions of the creditors meeting, determining the reorganization plan, reorganization procedures) involving a large number of different topics and Complex interests. Therefore, if the process needs to be controlled, the administrator, the court and the debtor must proceed in a consistent manner and cannot be controlled by a single party.

The key to the restructuring process is the ability to repay debts. The amount of debt needs to be determined according to the target company's specific assets, liabilities, and debt liquidation procedures. Since the enterprise still has some investment value, in order to ensure the success of the reorganization process, some investors should be identified in advance, or a backup plan should be drawn up. If the objective of the business is to continue to operate, it will also have to pay the costs required to operate, and liquidity is an important part of the business activities.
Therefore, in the reorganization proceedings, if the debtor lacks liquidity, it is necessary to carry out financing activities first to ensure that the reorganization proceedings can be opened normally. However, because the restructuring results are full of possibilities, financing is more difficult. The solution is to raise capital by setting up a new security interest, giving the creditors of the round of financing priority liquidation rights. The other is to allow shareholders to borrow money, because the success of the reorganization process will be directly related to the interests of shareholders, so shareholders for their own benefit should also make a certain contribution to the reorganization proceedings. [8]

\subsection{Mergers and Reorganizations}

Merger and reorganizations refer to the merger and transfer of equity in accordance with certain procedures because the debt of the enterprise is too heavy. Merger and reorganization is mainly based on the principle of voluntary consultation, the interests are all stained, risk sharing, to achieve win-win is its core concept. Overcapacity in the industry can be carried out through mergers and reorganizations, which can help "zombie enterprises" to clear up, optimize the structure of the industry layout, and can form a group of enterprises with comprehensive advantages.[9] Mergers and reorganizations take many forms, including debt-taking, capital purchase, holding, authorized operation, and merger.

\section{CONCLUSION}

Dealing with zombie enterprises is to ensure the transformation of economic structure and the upgrading of consumption. Zombie companies lead to misallocation of resources, occupying social capital, making it difficult for emerging companies to obtain funds, and hindering innovation and development. However, mainly due to potential financial risks and employee placement issues, zombie companies must be handled in an orderly manner. Carelessness can easily lead to social and economic stability. Banks, backed or encouraged by the government, inject large amounts of money into zombie companies, objectively with financial risk factors. Therefore, bankruptcy disposal of zombie companies must pass strict legislation, law enforcement and legal supervision to effectively solve financial risks, effectively protect the rights and interests of employees, and solve problems such as training and reemployment. 


\section{AUTHORS' CONTRIBUTIONS} Chen.

This paper is independently completed by Zijiong

\section{ACKNOWLEDGMENTS}

This paper was completed under the careful guidance of assistant teacher $\mathrm{Li}$, and thesis teacher Sun. Not only did I establish my future learning goals, but also mastered the basic research methods. From the topic selection to the completion of this thesis, every step was completed under their careful guidance, and a lot of effort was devoted. Here, I would like to express my respect and thanks.

\section{REFERENCES}

[1] Gao Meihui: "China's "zombie enterprise" identification and its market exit mechanism research," master's degree thesis, Suzhou University, 2017

[2] Chen Qinghua, "The Causes and Countermeasures of "Zombie Enterprises", "Small and Medium Enterprises in China", May 5,2016

[3] Yang Yanmei, Chen Yunming, Xu Jiyan, "The Reasons for Zombie Enterprises' Stiffness and Death", "Modern Economic Information", 18th issue of 2017

[4] Liu Aijun," Discussion on Zombie Enterprises", "Consumer Guide", July 2016

[5] Li Ruixin, "The Urgent Problem in the Bankruptcy and Liquidation of Zombie Enterprises", "Enterprise Reform and Management", 7th issue of 2020

[6] Wei Jie, Zhang Wei, "Enterprise Restructuring and "Zombie Enterprise" Countermeasure Inquiry", "China Market", 29th issue of 2017

[7] Chen Xu: "Cleaning Up "Zombie Enterprises" and Research on the Reform of State-owned Enterprises - Taking Shenzhen as an Example," Master's Degree Thesis, Central China Normal University, 2017

[8] Ma Suying, "Zombie Corporate Debt Disposal and Case Study", "Enterprise Reform and Management", 6th issue, 2020

[9] Wang Songzi: On the Formation of "Zombie Enterprises" and Its Legal Rules, Master's
Degree Thesis, Southwest University of Political Science and Law, 2017

[10] Zhao Yao: "The Identification and Response Policy of Commercial Banks in the Process of Identification and Clearance of Zombie Enterprises", Master's degree thesis, University of International Business and Economics, 2016 